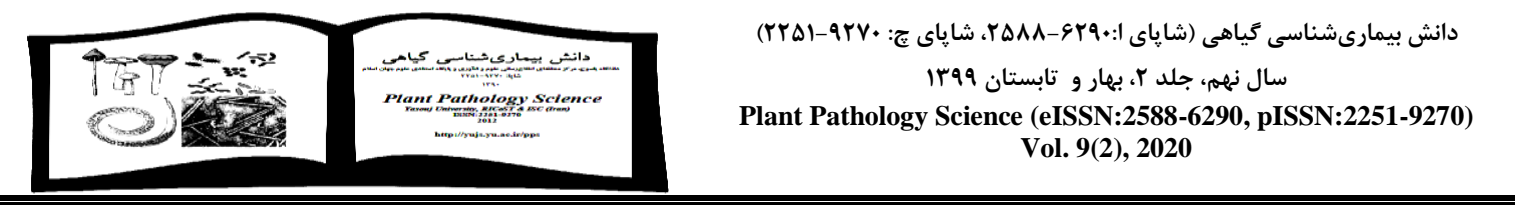

\title{
Research Article \\ Pathogenic variation of Didymella rabiei isolates causing Chickpea blight in three western provinces of Iran
}

\author{
SORAYA MIRZAPOUR, MOSTAFA DARVISHNIA ${ }^{\bowtie}$, \\ EIDI BAZGIR, HOSSEIN MIRZAEI NAJAFGHOLI \\ Department of Plant Protection, Faculty of Agriculture, \\ Lorestan University, Khorramabad, Iran
}

Received: 07.06.2020 Accepted: 12.23.2020

Mirzapour S, Darvishnia M, Bazgir E, Mirzaei Najafgholi H (2020) Pathogenic variation of Didymella rabiei isolates causing Chickpea blight in three western provinces of Iran. Plant Pathology Science 9(2):1-13. DOI: 10.2982/PPS.9.2.1

\begin{abstract}
Introduction: Chickpea blight, caused by Didymella rabiei, is the most limiting factor in chickpea production areas in the world, including the western provinces of Iran. The aim of this study was to investigate the pathogenic diversity of the isolates collected from western provinces of Iran (Ilam, Lorestan and Kermanshah) on differential lines of chickpea, as well as the relationship between pathogenic diversity of the isolates and their geographical origins. Materials and Methods: During the 2017-18 chickpea growing season, samples of infected plants were collected from fields in western provinces and transferred to the laboratory. Then 100 pure isolates of $D$. rabiei were obtained. Based on the location of collection, the isolates were divided into 20 groups. Based on the morphological characteristics, one isolate from each group was selected as a representative for greenhouse experiments. The pathogenic diversity of theses 20 isolates was assessed on eight differential lines of chickpea. The factorial experiments were performed in a completely randomized block design under greenhouse conditions. Results: The results of analysis of variance showed that there was a significant difference between differential lines and isolates at a probability level of $p<0.01$. Based on the response of the differential lines, the pathogenic isolates were grouped into three pathogenic groups, including pathogenic group 1 (weakly aggressive), group 2 (aggressive or moderately aggressive), and group 3 (highly aggressive). The isolates from Kermanshah and Lorestan Province were classified into Group 1 and the Ilam isolates into Groups 1,2 and 3. The greatest severity of the disease was found in three isolates of Ilam province. The variety ILC3996 showed the highest resistance to all isolates. Conclusion: D. rabiei isolates from three western provinces of Iran are divided into three pathogenic groups: 1 (low aggressive), 2 (moderately aggressive), and 3 (highly aggressive). Highly aggressive isolates identified in Ilam province can be used in chickpea breeding programs to produce resistant cultivars to the disease.. The wild variety ILC3996 has resistant genes against these pathogenic groups and showed resistance to all of these isolates.
\end{abstract}

Key words: Blight, Chickpea, Pathogenicity, Didymella rabiei

darvishnia.m@lu.ac.ir 


$$
\text { مقاله يزوهشى }
$$

\section{تنوع بيمارىزايى جدايههاى نidymella rabiei}

$$
\begin{aligned}
& \text { عامل سوختكى نخود در سه استان غربى ايران }
\end{aligned}
$$

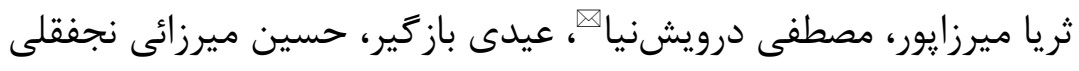

$$
\begin{aligned}
& \text { كروه ₹ياهيزشكى، دانشكده كشاورزى، دانشكاه لرستان }
\end{aligned}
$$

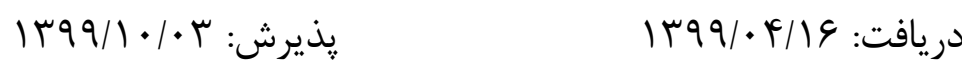

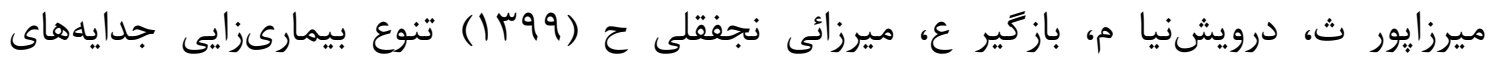
Didymella rabiei

DOI:10.2982/PPS.9.2.1

جكيده

مقدمه: سوختكى ناشى از Didymella rabiei مهمهرين عامل محدودكننده توليد نخود در جهان، از

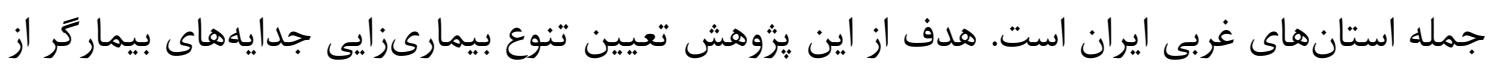

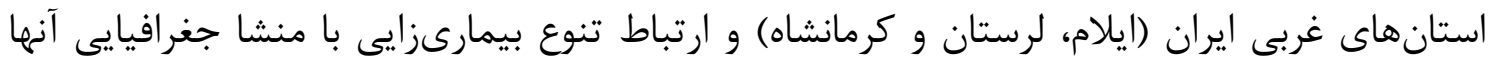

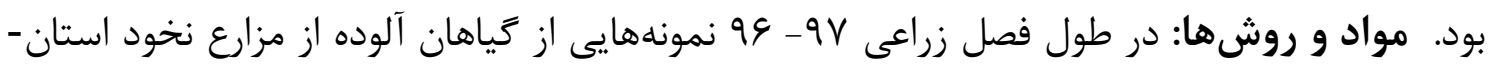

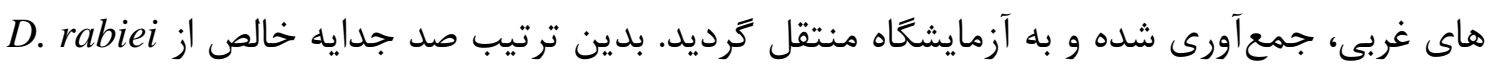

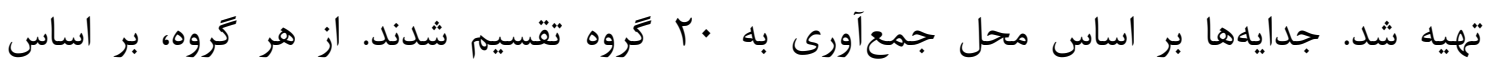

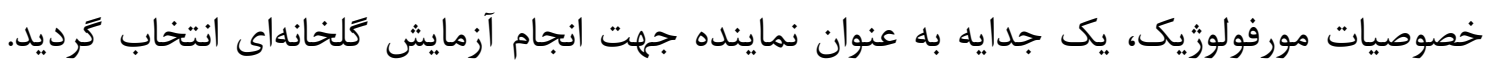

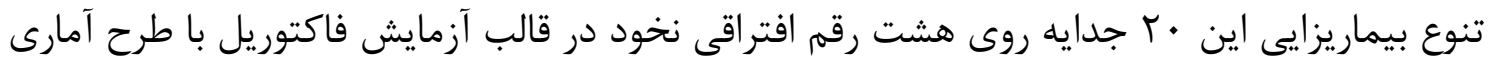

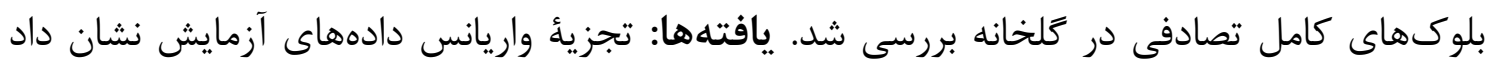

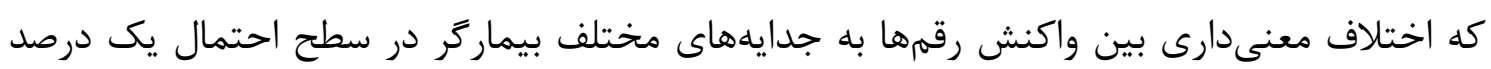

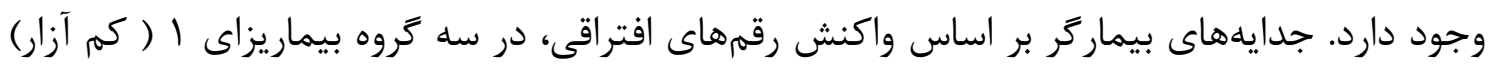

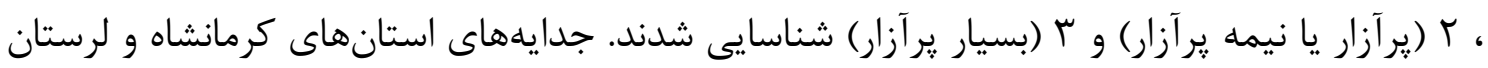

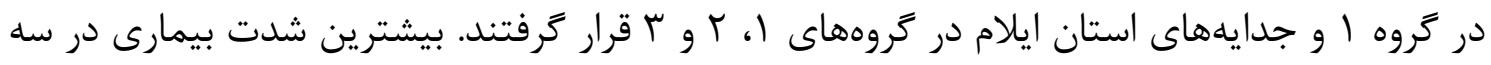

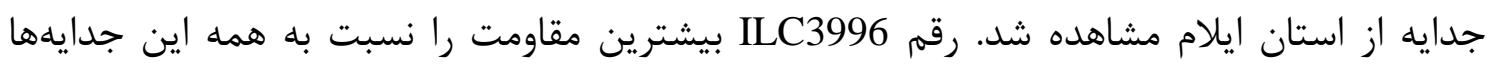

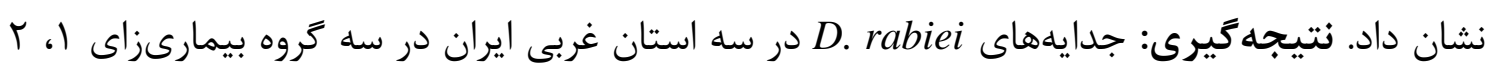

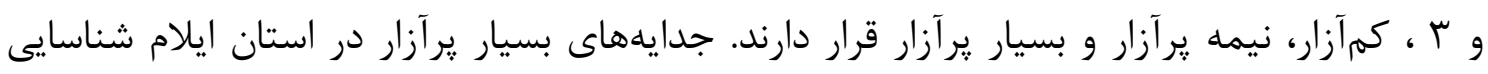

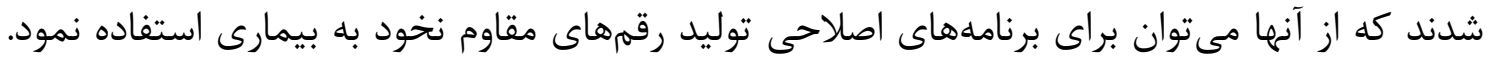

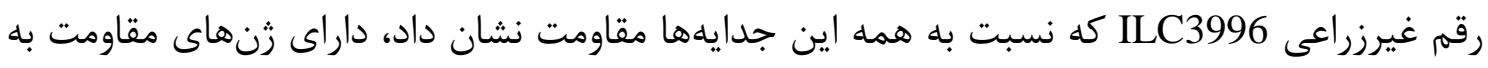
اين كروههاى بيمارىزاى بيماركر است

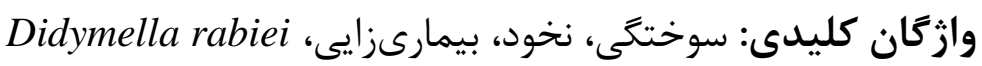

$\triangle$ darvishnia.m@lu.ac.ir 


\section{Introduction}

Chickpea (Cicer arietinum L.) is an important legume that can be grown under a wide range of agro-ecological conditions in the world, particularly in Asia and Africa (Baite et al. 2018). Chickpea plants play an essential role in sustainable agriculture through nitrogen fixation, which can add to the diversity of agricultural systems as a rotating crop (Vafaei et al. 2015). The western provinces of Iran, including Lorestan, Kermanshah, and Ilam, are the main regions of chickpea production. Chickpea plants are affected by both biotic and abiotic stresses which can affect their yields. Blight caused by Didymella rabiei Kovatsch. ex. Arx is the major biotic stress of chickpea. This pathogen is the world's most important limiting agent for chickpea production, which can cause high losses (over 90\%) during flowering to pod-set in the main chickpea production areas such as India, Pakistan, Syria, Iran, European and Mediterranean countries (Nourollahi et al. 2009, Gharacheh and Sadravi 2015, Pande et al. 2011, Sharma and Ghosh 2016). In Iran, blight disease of chickpea has been reported for the first time by Zalpour (1963) (Pouralibaba et al. 2008). In addition disease incidence has also been measured, and yield losses might be $100 \%$ under favourable environmental conditions (Vafaei et al. 2015). At present, the control of this disease is mostly done by disinfecting the seeds and applying chemical fungicides in the field, while the using of resistant cultivars is recommended as the best method for longterm management (Hamwieh et al. 2013). Since a high genetic variation exists D. rabiei isolates from different regions, the cultivars do not react similarly to the disease (Rahimi et al. 2013). So far, many researches have been conducted on the pathogenic variation of D. rabiei isolates, and several pathogenic groups of D. rabiei (6 to 16 pathogenic groups) have already been reported (Younesi et al. 2003, Ghiai et al. 2011, Vafaei et al. 2015). The study of the pathogen variation isolates can provide valuable information about the blight populations (Chongo et al. 2004). The variation in aggressiveness identified within D. rabiei recombinant population worldwide can affect the resistance of host genotypes (Peever et al. 2012, Mahiout et al. 2015, Tekin et al. 2017). In several studies, D. rabiei isolates have been categorized into physiological species, virulent forms, pathogenic groups, race or pathotypes, based on reactions of a set of chickpea differential cultivars (Chen et al. 2004, Nourollahi et al. 2009). Studies conducted on variation in aggressiveness within $D$. rabiei populations have revealed that isolates have different responses against host genotypes (Imtiaz et al. 2011, Baite et al. 2016). Jamil et al. (2000), classified 102 isolates of the pathogen into eight virulent forms from Pakistan. Understanding of the population diversity of D. rabiei isolates and the selection of resistant cultivars are necessary to achieve effective strategies for the disease managment. The using of resistant cultivars is the best management strategy to minimize yield losses due to blight. But due to the considerable variation in pathogenicity among fungal population and partial resistance in germplasm of chickpea the effectiveness of resistant cultivars is highly limited (Vafaei 2019). The present study was conducted to evaluate the pathogenic variation among D. rabiei isolates on chickpea differential lines in three western provinces of Iran and to understand the 
relationship between the pathogenic variation of fungal isolates and their geographical origin.

\section{Materials and Methods}

\section{Sampling and isolations of the pathogen}

During chickpea growing season of 2017-18, samples of infected plants (stems, pods, and seeds) were collected from fields of three western provinces of Iran including Lorestan, Ilam, and Kermanshah. The samples were surface sterilized with the commercial $1 \%$ sodium hypochlorite for one minutes, rinsed in sterile distilled water for $2 \mathrm{~min}$, and then dried through sterile filter papers. Samples were placed on chickpea seed meal dextrose agar (CSMDA) and then incubated under $12 \mathrm{~h}$ light/ $12 \mathrm{~h}$ dark alternating at $20^{\circ} \mathrm{C}$ for $7-10$ days (Dolar et al. 1994). Isolates were purified by single spore culture and identified based on morphological and cultural characteristics and named according to locations where collected (Mel'nik et al. 2000, Barnet and Hunter 1995).

\section{Pathogenicity test}

The pathogenicity test was conducted on susceptible cultivar Grit landrace, under the greenhouse condition. Suspension $2 \times 10^{5}$ conidia/ml, from fourteen days old cultures of D. rabiei isolates, were used for inoculation. The inoculated plants were covered with the translucent plastics which was removed after $48 \mathrm{hrs}$. High relative humidity was maintained by spraying sterilized water until the appearance of symptom. Disease severity was evaluated at 15 days after inoculation using Chongo et al. (2004) index (Table 1). Re-isolation of the pathogen was made from the diseased plants to confirm the identity of the pathogen and fulfill the Koch's postulates. Twenty isolates of the pathogen were selected that showed the highest severity of pathogenicity and were morphologically different. These twenty pathogen samples were selected from the three studied provinces and the pathogenicity of these isolates was evaluated.

جدول (. شاخص شدت بيمارى سوختكى نخود (Chongo et al. 2004) Table 1. Chickpea blight disease severity index (Chongo et al. 2004).

\begin{tabular}{cl}
\hline \hline Index & \multicolumn{1}{c}{ Observed symptoms } \\
\hline 0 & no symptoms \\
1 & few, very small $(<2 \mathrm{~mm} 2)$ lesions on leaves and stems, \\
2 & very small $(<2$ mm2) lesions, $2-5 \%$ PAA \\
3 & many small lesions ( $<2$ to 5 mm2), 5-10\% PAA \\
4 & many small lesions, few large ( $>5$ mm2) lesions, 10 to 25\% PAA \\
5 & many large lesions, 25-50\% PAA \\
6 & lesions coalescing, 50-75\% PAA \\
7 & lesions coalescing with stem girdling, 75-90\% PAA \\
8 & stem girdling or breakage, >90\% PAA \\
9 & plants dead \\
\hline
\end{tabular}




\section{Identification of pathogenic groups of Didymella rabiei isolates}

The experiment was conducted to assess the effects of the 20 pathogenic isolates on the eight chickpea differential lines selected on the basis of previous studies (Chen et al. 2004, Vafaei et al. 2015). Eight chickpea differential lines including ILC3279, ILC1929, ILC72, ILC249, ILC202, ILC194, ILC3996 and ILC482 were obtained from Agricultural Research Education and Extension Organization Karaj, Iran. Seeds were surface sterilized in $0.5 \%$ sodium hypochlorite for one minutes and washed in sterilized distilled water three times for 3 minutes. The plastic pots $(5 \mathrm{~cm}$ diameter) was filled with $500 \mathrm{gr}$ (mixture of autoclaved sand and clay with $3: 1, \mathrm{v} . \mathrm{v}$ ). Four seeds were planted in the pots under the greenhouse condition. Conidia of individual 20 isolates were harvested from fourteen days old cultures on CSMDA medium by flooding pycnidial bearing colonies with sterile distilled water and dislodging spores with a sterile glass rod. Fourteen days old plants were inoculated by spraying a spore suspension $\left(2 \times 10^{5}\right.$ conidia/ml), and immediately covered with the translucent plastics. The pots were kept at $20 \pm 1^{\circ} \mathrm{C}$ and $80 \%$ relative humidity for 28 days with 12 -hour light period, irrigated every 48 hours (Chongo et al. 2004, Nourrollahi et al. 2009). Control plants were sprayed with distilled water. The greenhouse experiment was a three factorial randomized complete block design (differential lines $\times$ different fungal isolates $\times$ times after pathogen inoculation) with three replications. The disease severity of twenty representative isolates on the eight chickpea differential lines at 28 days after pathogen inoculation was assessed with Chongo et al. (2004) index. The isolates which showed two or more similar reactions on the differential lines were grouped based on resistant/ to susceptible so as to classify for pathogenic groups of D. rabiei. Analysis of variance (ANOVA) was performed for the disease parameters using the Statistical Analysis System (SAS) 9.1.3 software. Tukey's test was used to separate the treatment means $(\mathrm{P}<0.05)$.

\section{Results}

\section{Pathogenicity of Didymella rabiei isolates and their morphological characteristics}

The pathogenicity of all $D$. rabiei isolates, confirmed by producing typical disease symptoms on the susceptible chickpea cultivar Grit landrace (Fig.1). Among 100 isolates of $D$. rabiei, 20 representative isolates from different geographical areas, which had the highest pathogenicity and different morphological characteristics, were selected for identification pathogenic groups. The representative isolates were different on CSMDA medium in some of the morphological characteristics such as radial growth on the medium, the colony color, pycnidia, and pycnidiospores size and form. Pycnidia form of the pathogen isolates from Ilam province were lime-shaped with two pores, while pycnidia types of those from Lorestan and Kermanshah provinces were pearshaped and spherical with single pore. The number of pycnidiospores in Lorestan isolates was smaller, but their sizes were longer than the pathogen isolates from Ilam and Kermanshah provinces (Figs. 2 and 3). 

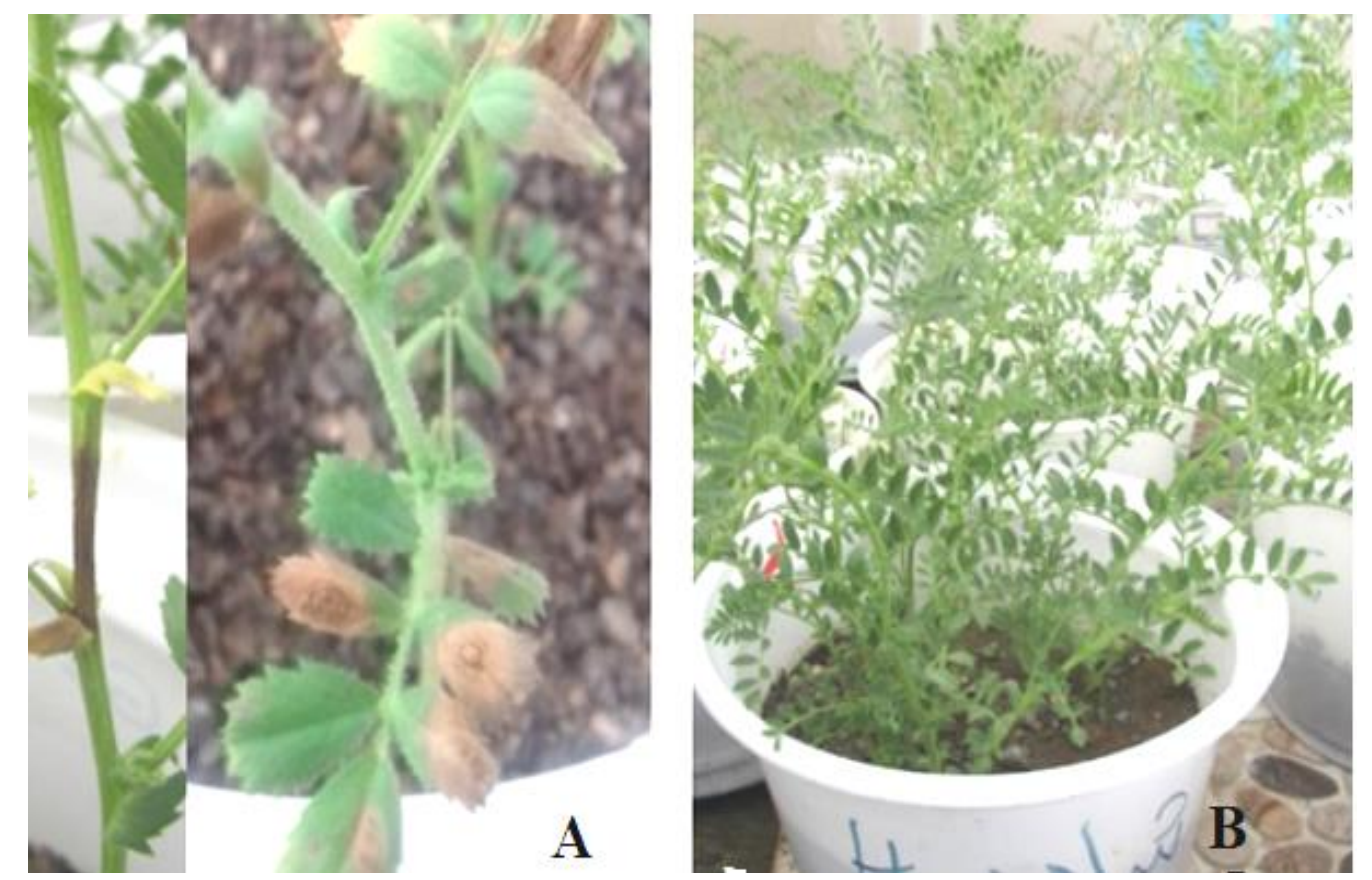

شكل I. A. نشانههاى بيمارى سوختكى گِ از تلقيح Didymella rabiei روى گياه نخود، B. شاهد سالم.

Figure 1. A. Symptoms of blight disease after artificial inoculation of Didymella rabiei on chickpea, B. Healthy check.
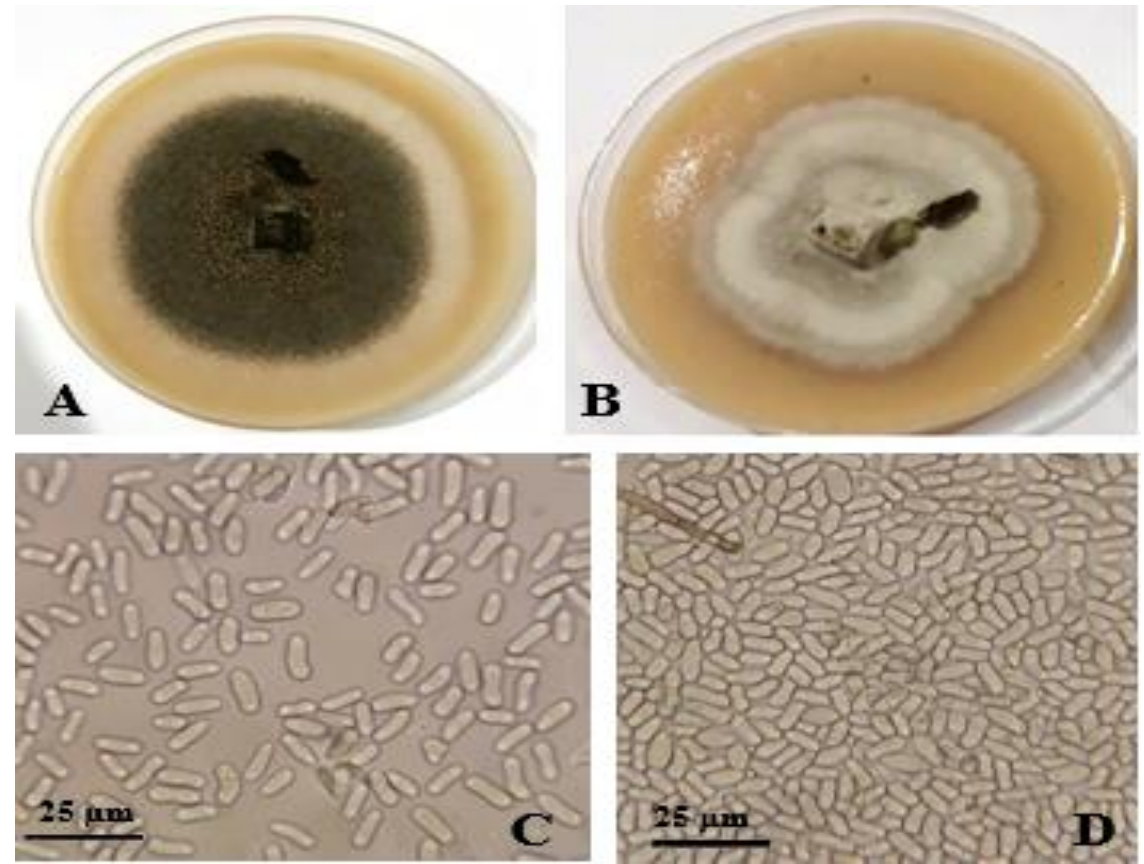

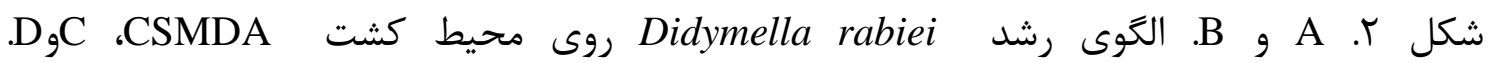
ريكنيد يوسيورها .

Figure 2. A,B. Growth pattern of Didymella rabiei on CSMDA medium, C,D. Pycnidiospores. 

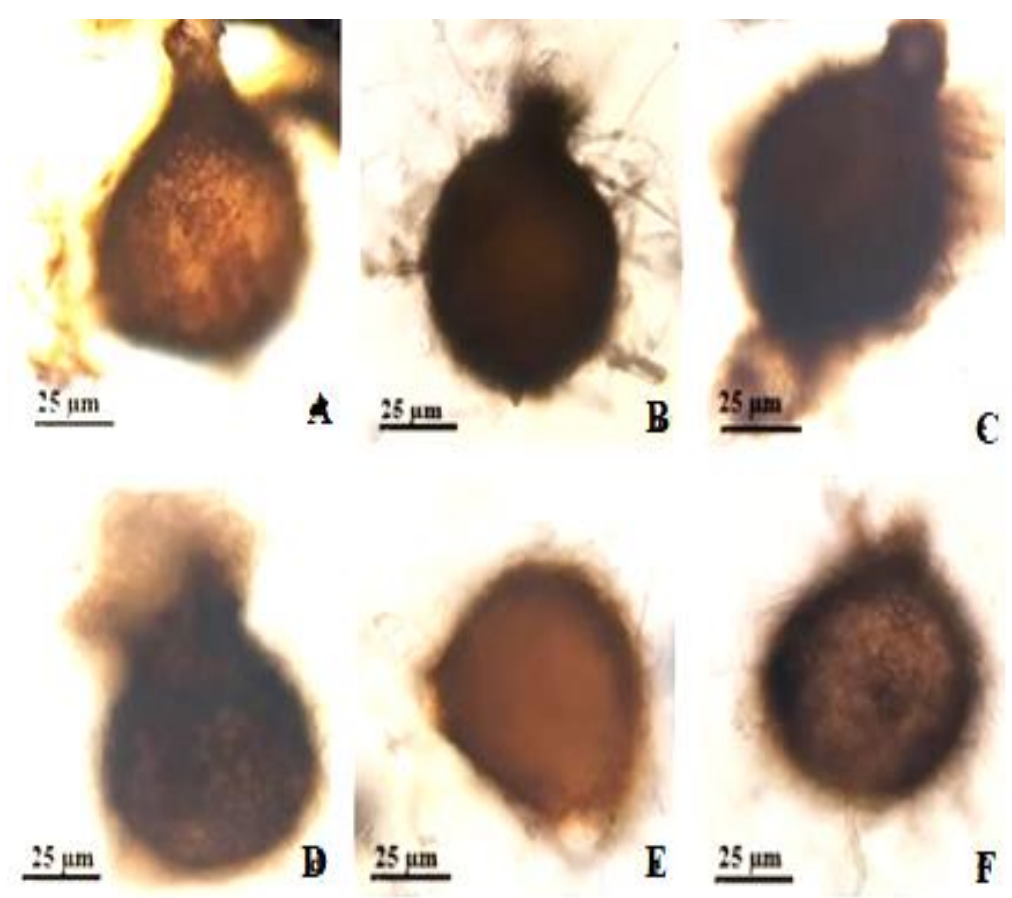

شكل س. شكلهاى مختلف پيكنيد بين جدايههاى Didymella rabiei جمعآورى شده از اسـتانهـاى

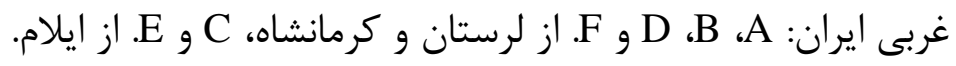

Figure 3. Pycnidia different form among Didymella rabiei isolates collected from western provinces of Iran: A,B,D,F. From Loresta and Kermanshah , C,E. From Ilam.

The growth rate of the pathogen isolates was different $(\mathrm{p}<0.01)$ significantly on the CSMDA medium. L20, IL11, and IL8 isolates had the highest growth rate with a mean growth rate of $56.6 \mathrm{~mm} / \mathrm{d}, 65 \mathrm{~mm} / \mathrm{d}$, and $64.3 \mathrm{~mm} / \mathrm{d}$, respectively. Among fungal isolates, L19 isolate had the lowest growth.

\section{Pathogenic groups of Didymella rabiei isolates}

Seven days after inoculation, all treated plants showed typical symptoms. Initially, the tan to brown- black lesions surrounded by a yellow halo developed on the leaves were observed, which quickly became blighted and abscised. On the stems, the lesions were wholly girdled stems, and branches were dark-brown to black, by the lesions, and finally, all bushes died. The control plants remained healthy. The most virulent isolates killed susceptible lines two weeks after inoculation.

Data analysis of variance showed, there was a significant difference between the effect of the chickpea cultivars, pathogen isolates, the pathogen inoculum times and their interaction on disease severity of the disease. A significant difference $(\mathrm{p}<0.01)$ was observed between disease severity and eight chickpea differential lines (Table 2).

The result showed that there was a significant difference among isolates from western provinces, and therefore, the isolates were placed in various pathogenic groups. Three pathogenic groups, including least aggressive pathogens (group 1), aggressive or moderately aggressive pathogens (group 2) and highly aggressive pathogens (group 3) were identified by inoculation of 20 representative isolates of pathogen on eight chickpea differential lines (Table 3 ). 
جدول r. تجزيه واريانس شدت بيمارى سوختكى ناشى از • r جدايه قارت Didymella rabiei روى

$$
\text { هشت رقم افتراقى نخود. }
$$

Table 2. Analysis of variance of blight disease severity of twenty representative isolates of Didymella rabiei on chickpea differential lines.

\begin{tabular}{|c|c|c|c|c|c|}
\hline Source of variation & Df & Sum of squares & Mean square & F-value & P-value \\
\hline Replication & 2 & 0.537 & $0.268^{* *}$ & 4.9 & 0.008 \\
\hline Differentials(D) & 7 & 113.160 & $16.166^{* *}$ & 294.9 & 0.001 \\
\hline Isolate (I) & 19 & 130.281 & $6.857^{* *}$ & 125.1 & 0.001 \\
\hline Time $(\mathrm{T})^{*}$ & 3 & 389.834 & $129.945^{* *}$ & 237.8 & 0.001 \\
\hline $\mathrm{D} \times \mathrm{I}$ & 133 & 49.650 & $0.373^{* *}$ & 6.8 & 0.001 \\
\hline $\mathrm{D} \times \mathrm{T}$ & 21 & 5.829 & $0.278^{* *}$ & 5.1 & 0.001 \\
\hline $\mathrm{I} \times \mathrm{T}$ & 57 & 18.525 & $0.325^{* *}$ & 5.9 & 0.001 \\
\hline $\mathrm{D} \times \mathrm{I} \times \mathrm{T}$ & 399 & 19.681 & $0.049^{\mathrm{ns}}$ & 0.9 & 0.898 \\
\hline Error & 1278 & 70.049 & $0.055^{*}$ & & \\
\hline Total & 1919 & 797.543 & & & \\
\hline C.V $(\%)$ & 12.7 & & & & \\
\hline
\end{tabular}

جدول r. واكنش هشت رقم افتراقى نخود به • ب جدايه Didymella rabiei از سه استان غربى ايران. Table 3. The reaction of eight chickpea differential lines to twenty isolates of Didymella rabiei from three provinces of western Iran.*

\begin{tabular}{|c|c|c|c|c|c|c|c|c|c|c|}
\hline \multirow{3}{*}{ Location } & \multirow{3}{*}{ Isolate } & \multirow{3}{*}{ Group } & \multicolumn{8}{|c|}{ Differential lines } \\
\hline & & & ILC & ILC & ILC & ILC & ILC & ILC & ILC & ILC \\
\hline & & & 3996 & 1929 & 202 & 194 & 72 & 249 & 3279 & 482 \\
\hline Kermanshah & K1 & I & $\mathrm{R}$ & $S$ & $\mathrm{R}$ & $\mathrm{R}$ & $\mathrm{R}$ & $\mathrm{R}$ & $\mathrm{R}$ & $\mathrm{R}$ \\
\hline Kermanshah & $\mathrm{K} 2$ & I & $\mathrm{R}$ & S & $\mathrm{R}$ & $\mathrm{R}$ & $\mathrm{R}$ & $\mathrm{R}$ & $\mathrm{R}$ & $\mathrm{R}$ \\
\hline Kermanshah & K3 & I & $\mathrm{R}$ & $\mathrm{S}$ & $\mathrm{R}$ & $\mathrm{R}$ & $\mathrm{R}$ & $\mathrm{S}$ & $\mathrm{S}$ & $\mathrm{R}$ \\
\hline Kermanshah & K4 & I & $\mathrm{R}$ & $\mathrm{S}$ & $\mathrm{R}$ & $\mathrm{R}$ & $\mathrm{R}$ & $\mathrm{R}$ & $\mathrm{R}$ & $\mathrm{R}$ \\
\hline Kermanshah & K5 & I & $\mathrm{R}$ & $\mathrm{S}$ & $\mathrm{R}$ & $\mathrm{R}$ & $\mathrm{R}$ & $\mathrm{R}$ & $\mathrm{R}$ & $\mathrm{R}$ \\
\hline Ilam & IL6 & I & $\mathrm{R}$ & S & $\mathrm{R}$ & $\mathrm{R}$ & $\mathrm{R}$ & $\mathrm{R}$ & $\mathrm{R}$ & $\mathrm{R}$ \\
\hline Ilam & IL7 & I & $\mathrm{R}$ & $\mathrm{S}$ & $\mathrm{R}$ & $\mathrm{R}$ & $\mathrm{R}$ & $\mathrm{R}$ & $\mathrm{R}$ & $\mathrm{R}$ \\
\hline Ilam & IL8 & Ш & $\mathrm{S}$ & $\mathrm{S}$ & $\mathrm{S}$ & $\mathrm{S}$ & $\mathrm{S}$ & $\mathrm{S}$ & $\mathrm{S}$ & $S$ \\
\hline Ilam & IL9 & II & $\mathrm{S}$ & $\mathrm{S}$ & $\mathrm{S}$ & $\mathrm{S}$ & $\mathrm{S}$ & $\mathrm{S}$ & $\mathrm{S}$ & $\mathrm{S}$ \\
\hline Ilam & IL10 & Ш & $S$ & S & S & $\mathrm{S}$ & $\mathrm{S}$ & $\mathrm{S}$ & S & $\mathrm{S}$ \\
\hline Lorestan & L11 & I & $\mathrm{R}$ & $\mathrm{S}$ & $\mathrm{R}$ & $\mathrm{R}$ & $\mathrm{R}$ & $\mathrm{R}$ & $\mathrm{R}$ & $\mathrm{R}$ \\
\hline Lorestan & L12 & I & $\mathrm{R}$ & $S$ & $\mathrm{R}$ & $\mathrm{R}$ & $\mathrm{R}$ & $\mathrm{R}$ & $\mathrm{R}$ & $\mathrm{R}$ \\
\hline Lorestan & L13 & I & $\mathrm{R}$ & $\mathrm{S}$ & $\mathrm{R}$ & $\mathrm{R}$ & $\mathrm{R}$ & $\mathrm{R}$ & $\mathrm{R}$ & $\mathrm{R}$ \\
\hline Lorestan & L14 & I & $\mathrm{R}$ & $S$ & $\mathrm{R}$ & $\mathrm{R}$ & $\mathrm{R}$ & $\mathrm{R}$ & $\mathrm{R}$ & $\mathrm{R}$ \\
\hline Lorestan & L15 & I & $\mathrm{R}$ & $\mathrm{S}$ & $\mathrm{R}$ & $\mathrm{R}$ & $\mathrm{R}$ & $\mathrm{R}$ & $\mathrm{R}$ & $\mathrm{R}$ \\
\hline Lorestan & L16 & I & $\mathrm{R}$ & $\mathrm{S}$ & $\mathrm{R}$ & $\mathrm{R}$ & $\mathrm{R}$ & $\mathrm{R}$ & $\mathrm{R}$ & $\mathrm{R}$ \\
\hline Lorestan & L17 & I & $\mathrm{R}$ & $\mathrm{S}$ & $\mathrm{R}$ & $\mathrm{S}$ & $\mathrm{S}$ & $\mathrm{S}$ & $\mathrm{S}$ & $\mathrm{R}$ \\
\hline Lorestan & L18 & I & $\mathrm{R}$ & $\mathrm{S}$ & $\mathrm{S}$ & $\mathrm{S}$ & $\mathrm{S}$ & $\mathrm{S}$ & $\mathrm{S}$ & $\mathrm{R}$ \\
\hline Lorestan & L19 & I & $\mathrm{R}$ & $\mathrm{S}$ & $\mathrm{R}$ & $\mathrm{S}$ & $\mathrm{R}$ & $\mathrm{R}$ & $\mathrm{R}$ & $\mathrm{R}$ \\
\hline Lorestan & L20 & I & $\mathrm{R}$ & $\mathrm{S}$ & $\mathrm{R}$ & $\mathrm{R}$ & $\mathrm{R}$ & $\mathrm{R}$ & $\mathrm{R}$ & $\mathrm{R}$ \\
\hline
\end{tabular}


The highest and lowest level of pathogenicity was observed in ILC1929 and ILC3996 lines as 5.74 and 2.27, respectively. The comparison of mean showed a significant difference $(p<0.001)$ between the disease severity and differential lines. The differential lines were placed in four levels of resistance. ILC1929 line showed the highest disease severity with a mean disease scale of 6 and introduced as highly susceptible line and located in group 4. In contrast, the lowest disease severity was observed in ILC3996 line, with a mean disease scale of 2.5 and considered as a highly resistant line and placed in group 1.

There was a significant interaction between inoculation time and pathogen isolates $(\mathrm{p}<0.01)$ (Table 2). As the time of inoculation increased, the disease severity also increased for all pathogen isolates. Seven days after the pathogen inoculation, there was no statistically significant difference between the majorities of populations, but significant difference was observed in disease severity between isolates as inoculation time increased, so that at 14, 21 and 28 days after inoculation, The highest amount of pathogenicity was observed at day 28 after the inoculation with the mean of 5.21.

\section{Discussion}

Understanding the pathogenic variability seems to be essential for development of resistant cultivars. In this present study, the isolates of D. rabiei collected from western provinces of Iran including Ilam, Lorestan, and Kermanshah were analyzed for their pathogenic variability. The reason of the studding of this case was that these chickpeas planted in these areas are highly infected with chickpea blight disease, and the disease's outbreaks and a hot spots occurrence primarily due to favorable weather conditions during spring seasons. All hundred isolates of pathogen confirmed to be pathogenic on the susceptible host (Grit landrace). The differential lines exhibited variable reactions against different isolates of the pathogen. Differential lines were susceptible to IL8, IL9, and IL10 isolates, whereas ILC1929, showed the highest susceptibility to all isolates. The ILC3996 line was highly resistant and proved to be resistant against majority of the isolates, ILC3279 and ILC249 were also susceptible to the K3 isolates collected from Kermanshah. The ILC72, ILC3279, ILC249 and ILC194 were resistant to L18, and L17 isolates, and ILC202 was resistant to L18 isolates, collected from Lorestan (Table 3). Similar results have been reported by Pourali Baba et al. (2008), who used two groups of cultivars, including ILC1929, ILC3996, ILC72, and ILC202. The his results showed that three pathogenic pathotypes were in Sararood, Gorgan of Ilam and Gachsaran, three in Klibro and six in Ilam in different years. Due to this variability in their reactions the isolates were placed into different groups. The isolates of D. rabiei were grouped into three categories, including least aggressive pathogens (group 1), aggressive or moderately aggressive pathogens (group 2), and highly aggressive pathogens (group 3) (Table 3). Many researchs have been conducted on the pathogenic variation of $D$. rabiei isolates in Iran, six pathotypes from 16 provinces ( Shokouhifar et al. 2003), eight pathogenic group in Kermanshah and Ilam (Nourrollahi et al. 2009), six races in Kermanshah (Paymard et al. 2014) and six pathogenic group from Lorestan, Kermanshah and Ilam have been reported (Vafaei et al. 2015). Subsequently, 14 pathotypes using eight chickpea differentials and 58 isolates were reported from most of countries (Chongo et al. 2004). Four races/pathotypes of D. rabiei were described in Algeria (Benzohra et al. 2011) and in Syria (Atik et al. 2013) while six races of D. rabiei were reported from Turkey using seven chickpea cultivars (Turkkan and Dolar 2009). Likewise, three pathotypes of D. rabiei detected using 11 chickpea lines in north 
western Algeria (Mahiout et al. 2015) and Pakistan ( Hina et al. 2013). In India, based on the reactions 25 isolates $D$. rabiei on ten chickpea differential genotypes, the population of D. rabiei were grouped into seven races (Baite et al., 2018). Three isolates (IL8, IL9, and IL10) from Ilam province were placed in groups 2 and 3 as aggressive and highly aggressive isolates so that these isolates were pathogenic on all the chickpea differential lines. The lowest disease severity was also found in the L16, L14 and L12 isolates (Table 3). In this study, D.rabiei isolates collected from Kermanshah and Lorestan provinces were less aggressive than those collected from Ilam. Vafaei et al. (2015) reported two and three highly aggressive isolates from Lorestan and Kermanshah provinces, respectively, whereas Ghiai et al. (2011) identified only one highly aggressive of $D$. rabiei isolate collected from Kermanshah. The differential lines exhibited the variable reactions in the interaction with the different pathogen isolates. The differential lines variation is necessary for identification and differentiation the rate of pathogenicity. The presence of resistance genes in this plant may be the reason why this cultivar is resistant to the disease (Imtiaz et al. 2011). Mehmood et al. (2017), in Australia, found that among 260 isolates of D. rabiei tested on four chickpea genotypes, only 54 isolates were highly aggressive, and placed them in four highly aggressive groups. In present study, the small value of variance was obtained from the interaction of the pathogen isolates $\times$ differential cultivars (mean square). Then it was impossible to classify D. rabiei isolates into race or pathotypes (Table 2). It has stated that pathogenic variation among $D$. rabiei isolates is due to the differences in aggressiveness but not virulence; hence, the pathogen population cannot be classified as a race or pathotype (Vail and Banniza 2008). The observed pathogenic groups' might be due to the incorrect sampling results and /or the difference in pathogenicity and host resistance. The lack of sexual reproduction of isolates with different pathogenicity can be due to the presence of geographical barriers or resistant cultivars (Peever et al. 2012). The reason for this grouping is lack of availability in standard differential genotypes and a highly variable pathogen population. A gene-for-gene relationship among the isolates of D. rabiei is still ambiguous, and a precise standard system not yet been introduced for the determination of the physiological races (Ghiai et al. 2011). Therefore, insufficient knowledge in the pathogenic genetics, the lack of a fully resistant genotype, and the lack of an accepted standard system for the naming of the race, make the researchers believe that the definition of race or pathotype is optional. Several factors are proposed as the reasons for appearance of high-pathogenic phenotypes including the sexual reproduction and recombination within the $D$. rabiei population, host resistance increasing to the local pathogen population, and selective pressure on different levels of host resistance in winter crops (Peever et al. 2012). We found that the weather and agricultural conditions is favorable for this pathogen is in Ilam province where highly aggressive D. rabiei isolates were isolated. The several conditions such as non-rotation in cultivated chickpea fields, favor temperature, and the presence of the sexual form of D. rabiei in these regions (Ilam province) the main causes for the appearance of the aggressive isolates. Different pathogenic groups exists in some regions therefore, susceptible cultivars might be resistant to the pathogen, in other words, variation in the pathogenicity of the pathogen, are due to the different pathogenic groups in regions. Therefore, the appearance of different pathogenic groups might be caused by variation in pathogenicity of native isolates papulation (Chongo et al. 2004). Difference in the reaction of cultivars against $D$. rabiei isolates from different regions showed the necessity of conducting the present study. There are a wide range of pathogenic 
variation among the D. rabiei isolates in Iran (Nourrollahi et al. 2009, Vafaei et al. 2015). The previous studies from the world's main areas cultivated chickpea have shown that D. rabiei isolates have a high variation in pathogenicity (Chen et al. 2004, Chongo et al. 2004, Baite et al. 2018).

\section{Conclusion}

Chickpea blight, caused by Didymella rabiei, is the most limiting factor in chickpea production areas in Ilam, Lorestan and Kermanshah provinces of Iran. D. rabiei isolates from these provinces are divided into three pathogenic groups: 1 (low aggressive), 2 (moderately aggressive), and 3 (highly aggressive). Highly aggressive isolates identified in Ilam province can be used in chickpea breeding programs to produce resistant cultivars to the disease. The wild variety ILC3996 has resistant genes against these pathogenic groups and showed resistance to all of these isolates.

\section{References}

1. Atik O, Seid A, Abang MM, Imtiaz M, Hamwieh A, Baum M, El-Ahmed A, Murad S, Yabrak MM (2013) Pathogenic and genetic diversity of Didymella rabiei affecting chickpea in Syria. Crop Protection 46:70-79

2. Baite MS, Dubey S, Singh B (2016) Morphological variability in the Indian isolates of Ascochyta rabiei causing blight in chickpea and evaluation of chickpea cultivars. Indian Journal Plant Protection 44:74-82.

3. Barnet HL, Hunter BB (1972) Illustrated Genera of Imperfect Fungi. Burgess Publishing Company, Minneapolis, USA, 241p.

4. Chen W, Coyne CJ, Peever TL, Muehlbaur FJ (2004) Characterization of chickpea differentials for pathogenicity assay of Ascochyta blight and identification of chickpea accessions resistant to Didymella rabiei. Plant Pathology Journal 53:759769 .

5. Chongo G, Gossen B, Buchwaldt L, Adhikari T, Rimmer S ( 2004) Genetic diversity of Ascochyta rabiei in Canada. Plant Disease 88:4-10.

6. Dolar FS, Tenuta A, Higgins VJ (1994) Detached leaf assay for screening chickpea for resistance to Ascochyta blight. Canadian Journal of Plant Pathology 16:215-220.

7. Gharacheh N, Sadravi M (2015) Five important fungal diseases of pulse crops in Iran. Plant Pathology Science 4(2):17-25.

8. Ghiai S, Razavi M, Shahriyari D (2011) Study on pathogenic and molecular variability in some isolates of Ascochyta rabiei causal agent of Ascochyta blight of chickpea in Iran. Entomology and Phytopathology Journal 79:199-218. (In Persian with English Abstract).

9. Hamwieh A, Imtiaz M, Hobson K, Kemal SA (2013) Genetic diversity of microsatellite alleles located at quantitative resistance loci for Ascochyta blight resistance in a global collection of chickpea germplasm. Phytopathology Mediterranea 52:183-191. 
10. Hina A, Alam SS, Nayyer I (2013). Genetic and pathogenic variability of Ascochyta rabiei isolates from Pakistan and Syria as detected by universal rice primers. Journal of Plant Pathology and Microbiology 4:212.

11. Imtiaz M, Abang MM, Malhotra R S, Ahmed S, Bayaa B, Udupa SM, Baum M (2011) Pathotype IV, a new and highly virulent pathotype of Didymella rabiei, causing Ascochyta blight in chickpea in Syria. Plant Disease 95:1192-1192.

12. Jamil FF, Sarwar N, Sarwar M, Khan JA, Geistlinger J, Kahl G (2000) Genetic and pathogenic diversity within Ascochyta rabiei (Pass.) Lab. populations in Pakistan causing blight of chickpea (Cicer arietinum L.). Physiological and Molecular Plant Pathology 57:243-254.

13. Mahiout D, Bendahmane BS, Benkada MY, Rickauer M (2015) Physiological Characterisation of Ascochyta rabiei (Pass.) Lab. Isolated from diseased chickpea Fields in Six Regions of Northwestern Algeria. American-Eurasian Journal Agriculture \& Environment Science 15:1136-1146.

14. Mehmood Y, Sambasivam P, Kaur S, Davidson J, Leo AE, Hobson K, Linde C C, Moore K, Brownlie J, Ford R (2017). Evidence and consequence of a highly adapted clonal haplotype within the Australian Ascochyta rabiei population. Frontiers in Plant Science, 8:1029.

15. Mel'nik VA, Braun U, Hagedorn G (2000) Key to the Fungi of the Genus Ascochyta Lib. (Coelomycetes). Biologische Bundesanstalt für Land- und Forstwirtschaft, Berlin, Germany,192p.

16. Nourollahi K, Javannikkhah M, Naghavi MR, Okhovat SM (2009) Pathogenic diversity in Didymella rabiei from the western Iranian Ilam and Kermanshah provinces. Journal of Plant Protection 23:56-65. (In Persian with English Abstract).

17. Pande S, Sharma M, Gaur PM, Tripathi S, Kaur L, Basandrai A, Khan T, Gowda CLL, Siddique KHM (2011) Development of screening techniques and identification of new sources of resistance to Ascochyta blight disease of chickpea. Australasian Plant Pathology 40:149-156.

18. Paymard A, Torabi M, Shahryari D (2014). Pathogenic variability of Didymella rabiei the agent of ascochyta blight of chickpea in Kermanshah province. Applied Plant Protection 3:73-85. (In Persian with English Abstract).

19. Peever T, Chen W, Abdo Z, Kaiser W (2012) Genetics of virulence in Ascochyta rabiei. Plant Pathology 61:754-760

20. Pouralibaba H, Mahmodi F, Keshavarz K, Nourollahi KH (2008) Identification of pathotypes of Didymella rabiei causing agent of chickpea blight disease in different parts of Iran using trap nursery. Journal of Plant Pathology 44:170-175. (In Persian with English Abstract).

21. Rahimi M, Sabbagh SK, Nikkhah MJ, Salari M, Panjekeh N (2013) Study of genetic diversity of $A$. rabiei the causal agent of chickpea Ascochyta blight by SSR marker in Lorestan province. Journal of Plant Protection Science 44:273-282. (In Persian with English Abstract).

22. Sharma M, Ghosh R (2016) An update on genetic resistance of chickpea to ascochyta blight. Agronomy 6:18. 
23. Shokouhifar F, Bagheri A, Falahati RM, Malekzadeh S (2003) Pathotyping of Ascochyta rabiei isolate in Iran. Journal of Agricultural Sciences and Natural Resources 1:217-232. (In Persian with English Abstract).

24. Tekin M, Sari D, Catal M, Ikten C, Smykal P, Penmetsa RV (2017) Ecogeographic distribution of Cicer arietinum PH Davis and threats to the species. Genetic Resources and Crop Evolution 65:67-77

25. Turkkan M, Dolar FS (2009) Determination of pathogenic variability of $D$. rabiei, the agent of ascochyta blight of chickpea in Turkey. Turkish Journal of Agriculture and Forestry 33:585-591.

26. Vafaei SH (2019) Blight disease of chickpea. Journal of Plant Pathology 8:4557. (In Persian with English Abstract).

27. Vafaei SH, Rezaee S, Abasi Moghadam A, Zamanizadeh H R (2015) Virulence diversity of A. rabiei the causal agent of Ascochyta blight of chickpea in the western provinces of Iran. Archives of Phytopathology and Plant Protection 48:921-930.

28. Vail S, Banniza S (2008) Structure and pathogenic variability in Ascochyta rabiei populations on chickpea in the Canadian prairies. Plant Pathology 57:665673.

29. Younesi H, Okhovvat SM, Hadjaroude GA, Zad SJ, Talei AR, Zamani M (2003) Virulence variability of Ascochyta rabiei isolates on chickpea cultivars in Kermanshah province. Journal of Plant Pathology 39:213-228. (In Persian with English Abstract). 